УДК 378.147:373.3.091

DOI:

Олена Кравченко-Дзондза, кандидат педагогічних наук, доцент кафедри філологічних дисциплін та методики їх викладання у початковій школі Дрогобицького державного педагогічного університету імені Івана Франка

\title{
КУЛЬТУРОЛОГІЧНА КОМПЕТЕНТНІСТЬ МАЙБУТНЬОГО ВЧИТЕЛЯ В КОНТЕКСТІ КУЛЬТУРОЛОГІЧНОЇ ПАРАДИГМИ ОСВІТИ
}

Стаття присвячена одному з аспектів професійної підготовки майбутнього педагога - формуванню культурологічної компетентності. Розглядається питання формування культурологічної компетентності майбутніх учителів у процесі вивчення украӥнської та світової літератури, історії культури. Обгрунтовано роль культурологічної парадигми освіти у формуванні культурологічної компетентності студента. Автор з'ясовує роль нормативних і вибіркових навчальних курсів у формуванні культурологічної компетентності вчителя; ознайомлює з основними методами і прийомами навчання.

Ключові слова: компетентність; культурологічна парадигма; культурологічна компетентність; культура; література; педагогічна освіта; професійна компетентність.

תim. 6.

Olena Kravchenko-Dzondza, Ph.D.(Pedagogy), Associate Professor of the Philological Sciences and Techniques of Teaching in Elementary School Department Drohobych Ivan Franko State Pedagogical University

\section{FORMATION OF THE CULTURAL COMPETENCE OF FUTURE TEACHER IN THE CONTEXT OF CULTUROLOGICAL EDUCATIONAL PARADIGM}

The article reveals the theoretical approach to the determination of basics of notion "cultural competence". It has been proved that culture-focused approach is one of the leading as for tolerant personality's education in the intercultural environment. The role of culturological paradigm of education in formation of the students' cultural competence is substantiated.

Cultural competence is an important constituent of the modern professionals' competence. It makes a set of personal characteristics which allow a person to be aware of the variety of industries' culture. Cultural approach is one of the key ways in determining the content of education, upgrading education standards. Culture-focused preparation makes a basis for cultural competence which makes the cultural knowledge and skills mastering, guiding and forming the values-orientated students. Ukrainian and world literature as part of culture is an important means of cultural competence development. The author finds out the role of normative and selective training courses in the formation of the cultural competence of the teacher; introduces the basic methods and methods of study. The important task is before modern higher pedagogical education: to form the outlook of students, which is full of humanistic ideas, views, convictions, ideals of Ukrainian and world spiritual culture. The author defines the role of cultural competence in the structure of professional-pedagogical competence of the school teacher, as well as considers its components. The author supposes that cultural studies competence is the foundation for the realization of modern specialists, especially the teaching professionals' activity, considering the national cultures, traditions and world achievements which have universal significance.

Keywords: a competence; a cultural paradigm; a cultural competence; a culture; literature; pedagogical education; a professional competence.

П остановка проблеми. Сучасний освітній простір спрямований не тільки на набуття молоддю знань, умінь і навичок, а й на вдосконалення професійної компетентності, що сприяє інтелектуальному й культурному розвиткові особистості, формуванню в неї здатності швидко реагувати на запити часу. Сучасний педагог повинен стати суб'єктом культурно-історичного процесу, розуміти закономірності розвитку культури як процесу створення, збереження i трансляції загальнолюдських цінностей, розбиратися в традиціях, духовних пріоритетах не тільки своєї, а й інших націй; уміти спілкуватися в сучасному світі, оперуючи світовими культурними еталонами й образами. Розвиток і функціонування освіти зумовлюються чинниками, умовами та принципами існування суспільства, в тому числі принципом культуровідповідності, що передбачає організацію навчання у контексті культур, уважне вивчення цінностей рідної та іншомовної культур як передумови формування майбутнього вчителя. Такі вимоги виявили потребу у фахівцях зі сформованою 


\section{КУЛЬТУРОЛОГІЧНА КОМПЕТЕНТНІСТЬМАЙБУТНЬОГО ВЧИТЕЛЯ В КОНТЕКСТІ КУЛЬТУРОЛОГІЧНОӤПАРАДИГМИ ОСВІТИ}

культурологічною компетентністю. Тому однією 3 актуальних освітніх проблем є формування культурологічної компетентності майбутнього вчителя.

Аналіз останніх досліджень і публікацій. Питання реалізації культурологічного підходу в теорії та практиці вищої школи обгрунтовано у працях Є. Баллера, Є. Бондаревської, І. Зязюна, О. Рудницької, В. Сластьоніна та ін. Окремі аспекти культурологічної спрямованості підготовки майбутнього фахівця досліджуються упрацях Л. Буєвої, І. Луцької, В. Маслова, О. Попової, Н. Сердюк та ін. Культурологічною парадигмою сучасної освіти вони вважають рівноправну взаємодію учасників навчального процесу, спрямованого на формування у майбутніх вчителів мотивації та інтересу до культури іншого народу, розвиток аналітичних умінь, які будуть необхідні під час зіставлення та аналізування культурних явищ, способу життя чи ментальності того чи іншого етносу[5]. На їхню думку, культурологічна парадигма сприяє кращому розумінню особливостей професійної підготовки майбутніх учителів.

Мета статі - визначити зміст поняття “культурологічна компетентність” у контексті культурологічної парадигми освіти.

Виклад основного матеріалу. У контексті дослідження проблеми вважаємо доцільним акцентувати увагу на формулюванні поняття “культурологічна компетентність”. Аналіз філософської, психологічної педагогічної літератури вітчизняних і зарубіжних авторів показав, що на даний час існує два основних підходи до розкриття вміступонять “компетенція" i “компетентність”. У працях зарубіжних дослідників часом не розмежовуються поняття “компетенція / компетентність”. У зв’язку з цим, цілком слушно відзначити, що поняття “компетентність" та “компетенція" мають синонімічне значення для дослідників і включають характеристику діяльності.

Аналіз вітчизняної наукової літератури (Н. Бібік, Ю. Вторнікова, Л. Коваль, О. Овчарук, Л. Пєтухова, О. Пометун, О. Савченко, С. Скворцова та ін.) засвідчив диференціацію українськими науковцями понять компетенції та компетентності.

Так, О. Овчарук подає такі визначення цих понять [3, 5 - 14]:

- “компетентність” - це інтегрована характеристика якості особистості, результативний блок, сформований через досвід, знання, вміння, ставлення, поведінкові реакції. Компетентність побудована на комбінації взаємовідповідних пізнавальних відношень та практичних навичок, цінностей, емоцій, поведінкових компонентів, знань та вмінь, усього того, що можна мобілізувати для активної дії.

- “компетенція” - об'єктивна категорія, суспільно визнаний рівень знань, умінь, навичок, ставлень та ін. у певній сфері діяльності людини як абстрактного носія.

Поняття компетентності у світовій освітній практиці є ключовим, адже компетентність:

a) охоплює і знання, і навички діяльності;

б) складає основу інтерпретації змісту освіти, який сформований відповідно до очікуваного результату;

в) володіє інтегративним характером, адже поєднує низку умінь та навичок, які належать до широких сфер культури і діяльності.

У дослідженні ми поділяємо думку сучасних вітчизняних науковців, які під компетентністю розуміють інтегровану характеристику якостей особистості, результат підготовки випускника ЗВО до виконання діяльності в певних галузях (компетенціях). На їхню думку, компетентність, так само як і компетенція, містить у собі когнітивний (пізнавальний), мотиваційно-ціннісний й емоційно-вольовий компоненти. Компетентність - це ситуативна категорія, оскільки виражається в готовності до здійснення діяльності в конкретних професійних (проблемних) ситуаціях. Компетентність проявляється в особистісноорієнтованій діяльності. Тому прояв компетентності оцінюється на основі сформованої у випускника ЗВО сукупності вмінь (тих, що інтегративно відображають цю компетентність) і його поведінкових (психологічних) реакцій, що проявляються в різноманітних життєвих ситуаціях $[5,40]$.

Складовою професійної компетентності майбутнього вчителя $\epsilon$ культурологічна компетентність. На думку вчених культурологічна компетентність розглядається як сукупність знань про культуру в широкому та вузькому понятті цього слава, яка дозволяє намалювати цілісну картину світу та показати значення навчальної дисципліни для уточнення цієї картини, яка дозволяє визначити місце людини в світі та способи зміни світу з урахуванням отриманих знань [4] і передбачає сформованість гуманістичного бачення світу, духовноестетичних цінностей, власної думки і переконання, здібності стверджувати та відстоювати їх; необхідності літератури для саморозвитку і самореалізації духовного світу людини, для досягнення гармонійних стосунків індивідуума 3 навколишнім світом: осмислення 


\section{КУЛЬТУРОЛОГІЧНА КОМПЕТЕНТНІСТЬМАЙБУТНЬОГО ВЧИТЕЛЯ В КОНТЕКСТІ КУЛЬТУРОЛОГІЧНОЇПАРАДИГМИ ОСВІТИ}

внутрішньої єдності систем цінностей, відображених у літературі; здатність до критичного мислення, уміння протистояти антигуманістичним тенденціям у сучасній культурі; задоволення духовних запитів учнів, зумовлених психологічними особливостями старшого підліткового та юнацького віку [2, 69 79]. На нашу думку, культурологічна компетентність майбутнього вчителя - це цілісне, інтегративне, багаторівневе, особистісне новоутворення, що є результатом професійної підготовки майбутнього учителя у вищому закладі освіти та в процесі неперервної педагогічної освіти, успішність якої зумовлена сукупністю сформованих у фахівця компетенцій, які сприяють соціалізації особистості, формуванню в неї світоглядних та науково-професійних поглядів, формуванню педагогічної творчості та майстерності, визначають успішність професійної педагогічної діяльності, здатність до самореалізації, саморозвитку та самовдосконалення впродовж життя.

Показником сформованості культурологічної компетентності студентів $\epsilon$ уміння розглядати й аналізувати українську культуру в порівняльному аспекті, уміння засвоювати й оцінювати культурологічний досвід інших народів в контексті міжкультурних традицій, уміння розпізнавати національні цінності;уміння долати культурологічні перешкоди в умовах професійної діяльності.

Продиктований потребами сьогодення високий рівень вимог до освіти може бути реалізований тільки тоді, коли вчитель буде високопрофесійним, компетентним фахівцем у своїй галузі. Такий фахівець повинен не тільки сам мати фундаментальну освітню підготовку і володіти професійними знаннями та вміннями, відповідними рівню сучасної психологопедагогічної науки. Він повинен усвідомлювати значення своєї професійної праці в цілісній системі безперервної освіти, бути професійно мобільним, тобто гнучко реагувати на зміни соціальної ситуації розвитку школярів, опановувати новими психолого-педагогічними вимогами до педагогічного процесу і новими педагогічними технологіями . Це означає, що сучасний учитель - це творчий суб'єкт професійної педагогічної діяльності [1].

У сучасних вітчизняних і зарубіжних наукових дослідженнях 3 педагогіки обгрунтовується актуальність культуротворчої освіти у поєднанні 3 уявленням про формування гуманістичного типу особистості, перехід від ідеї “освіченої людини” до ідеї “людини культури”. Освіта у ХХІ столітті стає потужним механізмом формування культури соціуму, тому що вона є одним із важливих елементів i трансляторів культури як всеохоплюючого явища.

На основі зазначеного під культурологічною компетентністю ми розуміємо здібність майбутнього фахівця орієнтуватися в питаннях культури як цілісного феномена, сформованість умінь вписувати явища в $\dddot{11}$ контекст, усвідомлювати взаємозв'язок між різними галузями культури.

У тлумаченні поняття “культурологічна компетентність” виділимо такі суттєві ознаки:

a) належність культурологічної компетентності до інтелектуальних здібностей індивіда;

б) формування навичок грамотного використання культурної спадщини;

в) формування знань про культуру як цілісну систему, різноманіття культур у просторі й часі, взаємодію культур, типи культур, закономірності розвитку соціокультурного життя, закономірності художнього процесу, історію ментальностей за допомогою спеціально організованого навчання;

г) виховання потреб у правильній соціальнокультурній самоідентифікації людини, а через неї й суспільства в цілому;

д) утвердження національної, культурної, соціальної й релігійної толерантності (терпимості до чужих думок, вірувань, поведінки) як природної норми суспільної свідомості;

е) виховання культурою через занурення людини в їі багатовимірний простір.

Результатом формування культурологічної компетентності повинно стати вміння виробляти нову модель історичної й соціально-культурної самоідентифікації, нових шляхів розвитку, становлення нового типу духовності, зростання інформаційно-культурної проникності меж, подолання загальної кризи художньої культури.

Наприклад, вивчення студентами історії культури передбачає насамперед комплексне вивчення різних її сфер - історії науки й техніки, побуту, освіти, суспільної думки, фольклору й літератури, історії мистецтва. Ця узагальнююча дисципліна розглядає культуру як цілісну систему в єдності і взаємодії всіх її сфер. Вивчення історії культури дозволяє пізнати й виявити закономірності розвитку людського суспільства в цілому. В умовах докорінного ламання українського суспільства, переоцінки цінностей 3'явилася небезпека виникнення духовного вакууму. Руйнування звичного світоглядного комплексу привело людей до етичної дезорієнтації, відчуття розпаду звичних ціннісних норм і самого соціального змісту колективного буття суспільства. Навіть порівняно освічена частина 


\section{КУЛЬТУРОЛОГІЧНА КОМПЕТЕНТНІСТЬМАЙБУТНЬОГО ВЧИТЕЛЯ В КОНТЕКСТІ КУЛЬТУРОЛОГІЧНОЇПАРАДИГМИ ОСВІТИ}

населення іноді не в змозі сформулювати змістовну відповідь на актуальні ціннісні питання життя, виробити для себе стійкі орієнтації. Заповнити порожнечу, що утворюється, наситити iii конструктивним змістом може тільки долучення до культурних цінностей, які виробило людство протягом своєї багатовікової історії [6].

Реалізація культурологічного принципу навчання української та світової літератури в курсі “Дитяча література" майбутніми вчителями початкової школи передбачає висвітлення зв'язків літератури з філософією, міфологією, фольклором, звичаями, віруваннями, культурними традиціями різних народів і національностей. Ці зв'язки становлять ядро культурологічної лінії та потребують добору відповідного текстового та ілюстративного матеріалу. Культурологічна інформація, яка міститься в структурі літературно-художнього твору, передбачає використання таких методичних прийомів: культурологічний коментар чи культурологічна довідка; культурологічна характеристика літературного образу; постановка проблемних питань, за допомогою яких культурологічний матеріал пов'язують із аналізом твору; культурологічний аналіз, побудований на зіставленні художнього тексту з першоджерелом.

Для організації успішного й ефективного процесу формування культурологічної компетентності майбутнього учителя необхідна низка умов, які забезпечать досягнення поставленої мети. До них відносимо: вклячення майбутнього вчителя в активнутворчу діяльність, що стимулює пізнавальний інтерес до вивчення культури; створення на заняттях ситуацій успіху 3 опорою на міжпредметні зв'язки, допомога i контроль 3 боку викладача; активізація комунікативної та колективної взаємодії майбутніх вчителів засобами культуровідповідних форм і методів навчання; використання педагогічної та творчої рефлексії.

Таким чином, зростає значущість особистісно орієнтованого підходу до організації процесу формування комунікативної компетентності майбутніх учителів початкових класів. Особистісно орієнтований, суб' єкт-суб'єктний підхід передбачає, з одного боку, орієнтацію освітнього процесу на загальну мету - розвиток особистості, а з іншого - шлях реалізації цієї мети - суб'єкт-суб'єктна (реципроктна, гармонійна) взаємодія всіх учасників навчально-виховного процесу [5, 14].

Реалізація діяльнісного підходу досягається через навчальну діяльність іiі суб'єктів щодо оволодіння знаннями, вміннями та навичками відповідної професійної спрямованості. "При цьому така діяльність має бути адекватною їхньому практичному застосуванню у майбутній професійній діяльності, передбачає наповнення традиційних й новітніх навчальних форм діяльнісним змістом, спрямованим на оволодіння вміннями майбутньої професії, коли сама навчальна діяльність має моделювати на практично-теоретичному рівні професійні функції майбутнього фаху" [5, 14]. Застосування діяльнісного підходу у процесі формування культурологічної компетентності майбутніх вчителів спонукає студента до самостійності у здобутті знань, формуванні умінь та навичок та до ефективної організації діяльності. Цей підхід дає змогу навчити студента ставити перед собою мету, здійснювати самостійний пошук, аналіз, синтез та узагальнення нових знань.

3 позиції системного підходу культурологічна компетентність відображає сформованість у студентів професійно й особистісно осмислених знань, умінь та навичок, підкріплених мотивацією до вивчення культури.

Аналіз навчального плану та психологопедагогічної літератури, опитування студентів, результатів дослідження дозволяють зробити висновок про необхідність розробки навчальних курсів для формування культурологічної компетентності студентів-педагогів. Система вибіркових навчальних курсів дозволяє в поглибленій, розгорнутій формі озброювати студентів тими знаннями і вміннями, які потрібні для ефективної життєдіяльності майбутнього фахівця, але не входять до обов'язкової, інваріантної частини змісту вищої освіти. Кожна навчальна дисципліна володіє інформаційними, соціальними та технологічними властивостями. При цьому інформаційний аспект охоплює зміст навчального предмета, соціальний - суб'єктів навчальної діяльності, а технологічний - форми, методи, засоби, прийоми розгортання навчальної діяльності суб’єктів на основі інформаційного аспекту.

Проаналізувавши навчальні плани підготовки вчителя початкової школи у Дрогобицькому державному педагогічному університеті імені Івана Франка, ми дійшли висновку, що низка дисциплін, насамперед гуманітарних, сприяє формуванню культурологічної компетентності майбутнього фахівця. Проте переконані, що системно забезпечити формування культурологічної компетентності майбутнього вчителя початкової школи можна за допомогою вибіркових навчальних курсів, що пропонуються студентам: “Історія театру", “Історія мистецтв”, “Історія 


\section{КУЛЬТУРОЛОГІЧНАКОМПЕТЕНТНІСТЬМАЙБУТНЬОГО ВЧИТЕЛЯ В КОНТЕКСТІ КУЛЬТУРОЛОГІЧНОӤПАРАДИГМИ ОСВІТИ}

української культури". Саме вони дадуть змогу забезпечити формування культурологічної компетентності у сфері майбутньої професійної діяльності.

Висновки і перспективи подальших розвідок. Спираючись на положення, що культурологічна парадигма розглядається в науковій літературі як складова освітньої парадигми, відзначимо, що в основі професійної педагогічної підготовки вчителя є формування не тільки професійних умінь і навичок, а й здатності майбутнього вчителя через діалог культур досягти певного рівня самопізнання, ознайомитись із морально-етичними та культурними надбаннями інших народів, оволодіти певним культурознавчим мінімумом.

Культурологічний підхід у педагогічній освіті забезпечить формування культурологічної компетентності, а саме: формування навичок грамотного використання культурної спадщини; формування знань про культуру як цілісну систему, виховання потреб у правильній соціальнокультурній самоідентифікації людини, утвердження національної, культурної, соціальної толерантності.

У перспективі потребують детального розгляду дидактичні принципи, дотримання яких сприятиме успішній реалізації культурологічної парадигми освіти: принцип культуровідповідності, принцип діалогу культур, принцип єдності національного та загальнолюдського, принцип полікультурності, принцип використання культурознавчих завдань, принцип орієнтації на професію, принцип особистісного підходу, принцип діяльнісної основи навчання.

\section{ЛІТЕРАТУРА}

1. Кравченко-Дзондза О.Е. Компетентнісна парадигма підготовки майбутнього вчителя початкової школи / О. Кравченко-Дзондза // Молодь i ринок: Щомісячний науковопедагогічний журнал / Ред. кол. : Н.Примаченко (гол. ред.), Н. Скотна та ін. - 2017. - № 10 (153). - С. 84-90.

2. Музальов О. Культурологічна підготовка учнів професійно-технічних навчальних закладів / О. Музальов // Педагогіка і психологія професійної освіти. - 2003. - № 1. - С. 69-79.

3. Овчарук О.В. Розвиток компетентнісного підходу: стратегічні орієнтири міжнародної спільноти // Компетентнісний підхід у сучасній освіті: світовий досвід та українські перспективи: бібліотека з освітньої політики / Під заг. ред. О.В. Овчарук. - К.: “К.І.С.”, 2004. - 112 с.

4. Панкратова О. М. Культурологічна компетентністьвчителівііїформування/О.М.Панкратова. - Режим доступу: pier.ulstu.ru /seminar/ archive/ 29report.dok.

5. Професійна педагогічна освіта: компетентнісний підхід: монографія / за ред. О.А. Дубасенюк. Житомир: Вид-во ЖДУ ім. І. Франка, 2011. - 412 с.

6. Стеценко Н. М. Теоретичні підходи до інтерпретації сутності культурологічної компетентності / Н. М. Стеценко, Т. Г. Чикалова // Педагогічний альманах: [зб. наук. праць / редкол. В.В. Кузьменко (голова) та ін.] - Херсон: КВНЗ “Херсонська академія неперервної освіти”, 2014. - Вип. 23. - С.208-213.

\section{REFERENCES}

1. Kravchenko-Dzondza, O. (2017). Kompetentnisna paradyhma pidhotovky maibutnoho vchytelia pochatkovoi shkoly [Competency paradigm of the preparation of the future teacher of elementary school]. Youth and the market: Monthly scientific and pedagogical journal. Vol.10 (153). Drohobych, pp. 84-90.[in Ukrainian].

2. Muzalov, O. (2003). Kulturolohichna pidhotovka uchniv profesiino-tekhnichnykh navchalnykh zakladiv [Culturological training of students of vocational education institutions]. Pedagogy and psychology of vocational education. Vol.1, pp. 69-79. [in Ukrainian].

3. Ovcharuk, O.V. (2004). Rozvytok kompetentnisnogo pidxodu: strategichni oriyentyry mizhnarodnoyi spilnoty [Development of a competence approach: Strategic guidelines for the international community]. Kyiv: "K.I.S.", 112 p. [in Ukrainian].

4. Pankratova, O. (2015). Kulturolohichna kompetentnist vchyteliv i yii formuvannia [Cultural competence of teachers and its formation]. [Eectronic resource]. Available at: pier.ulstu.ru/seminar/ archive/ 29report.dok.[in Ukrainian].

5. Dubaseniuk, O.A. (Ed.). (2011). Profesijna pedagogichna osvita: kompetentnisnyj pidxid [Vocational pedagogical education: competence approach]. Zhytomyr: ZhDU by. I. Franko Publ., 412 p. [in Ukrainian].

6. Stetsenko, N. (2014). Teoretychni pidkhody do interpretatsii sutnosti kulturolohichnoi kompetentnosti [Theoretical approaches to the interpretation of the essence of cultural competence]. Pedagogical Almanac, vol. 23. Kherson: Kherson Academy of Continuing Education, pp.208-214. [in Ukrainian].

Стаття надійшла до редакції 31.07.2018 